LITERATURE REVIEW : PENGARUH TEKNIK RELAKSASI GENGGAM JARI TERHADAP PENURUNAN NYERI PADA KLIEN

POST OPERASI APENDIKTOMI

NASKAH PUBLIKASI

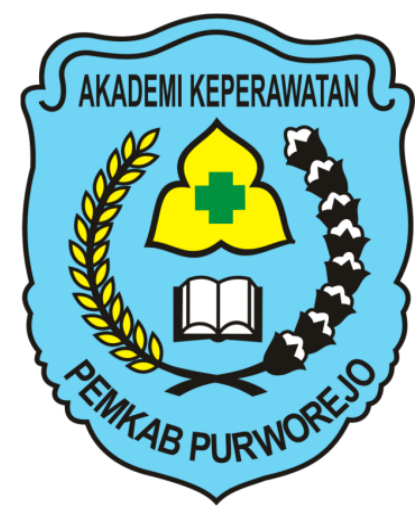

OLEH :

TAUFIQ NUR RAHMAAN

18090 
LITERATURE REVIEW: PENGARUH TEKNIK RELAKSASI GENGGAM JARI TERHADAP PENURUNAN NYERI PADA KLIEN POST OPERASI APENDIKTOMI

\section{NASKAH PUBLIKASI}

Diajukan sebagai salah satu syarat Mendapatkan Gelar Ahli Madya Keperawatan (A.Md. Kep) Pada Akademi Keperawatan Pemkab Purworejo

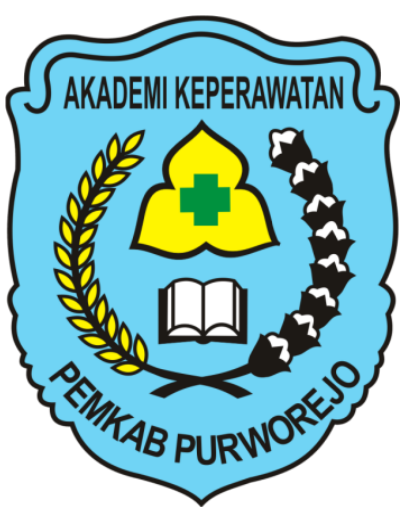

Oleh :

TAUFIQ NUR RAHMAAN 18090 


\section{LEMBAR PENGESAHAN}

Naskah Publikasi dengan judul "LITERATURE REVIEW : PENGARUH TEKNIK RELAKSASI GENGGAM JARI TERHADAP PENURUNAN NYERI PADA KLIEN POST OPERASI APENDIKTOMI" oleh Taufiq Nur Rahmaan (18090) telah diujikan di depan Dewan Penguji pada tanggal 23 Agustus 2021

Dewan Penguji :

Penguji I

Penguji II

Penguji III

Ahmad Muzaki., S.Kep., Ns., M.Kep NIDN : 0622038902

Mugihartadi., S.Kep., Ns., M.Kep NIDN : 0615078101
Wahyu Widodo, S.Kp., Ns., M.Kep

NIDN : 0609087301

Mengetahui,

Akademi Keperawatan Pemkab Purworejo

Direktur

Wahidin, S.Kep., Ns., M.Kep

NIDN : 0607118002 


\title{
LITERATURE REVIEW : PENGARUH TEKNIK RELAKSASI GENGGAM JARI TERHADAP PENURUNAN NYERI PADA KLIEN POST OPERASI APENDIKTOMI
}

\author{
Taufiq Nur Rahmaan ${ }^{1}$, Wahyu Widodo ${ }^{2}$, Mugihartadi ${ }^{3}$ \\ Mahasiswa Akademi Keperawatan Pemkab Purworejo ${ }^{1}$ \\ Dosen Akademi Keperawatan Pemkab Purworejo ${ }^{2}$ \\ Dosen Akademi Keperawatan Pemkab Purworejo ${ }^{3}$ \\ Purworejo, (0275)3140576 \\ Email :tnurahmaan14@gmail.com
}

\begin{abstract}
ABSTRAK
Latar Belakang : Apendisitis atau radang usus buntu yang terjadi pada organ kecil dan tipis, berbentuk kantong, berukuran 5 sampai $10 \mathrm{~cm}$ yang melekat pada usus besar. Tujuan : Mengetahui pengaruh teknik relaksasi genggam jari terhadap penurunan nyeri pada klien post operasi apendiktomi. Metode : Memakai metode literatur review. Pencarian artikel dilakukan dengan pendekatan data (data base) Google Scholar dengan menggunakan kata kunci seperti "teknik genggam jari”, + "penurunan nyeri" + "post operasi apendiktomi". Artikel yang dipilih adalah artikel yang diterbitkan dari tahun 2016 hingga 2021, dan teks lengkapnya dapat dilihat dalam format pdf bahasa Indonesia. Hasil : Berdasarkan kelima jurnal yang telah disajikan, menunjukan bahwa teknik genggam jari efektif dalam penurunan nyeri pada klien post operasi apendiktomi. Kesimpulan : Teknik genggam jari efektif dalam penurunan nyeri klien post operasi apendiktomi.
\end{abstract}

Kata kunci : teknik genggam jari, penurunan nyeri, post operasi apendiktomi

\begin{abstract}
Background : Appendicitis or appendicitis occurs in small and thin, pouch-shaped organs, measuring 5 to $10 \mathrm{~cm}$ that are attached to the large intestine. Objective : To determine the effect of finger grip relaxation techniques on reducing pain in postoperative appendectomy client. Method : Using the literature revies method. The search for articles was carried out using a Google Scholar data base approach using keywords such as "finger grip technique" + "pain reduction" + "post appendectomy surgery". The selected articles are articles published from 2016 to 2021, and the full text can be viewed in Indonesian pdf format. Results : Base on the five journals that have been presented, it shows that the finger grip technique is effective in reducing pain in post appendectomy surgery clients. Conclution : Finger grip technique is effective in reducing pain in post appendectomy surgery cliens.
\end{abstract}

Keywords : finger gripping technique, pain reduction, post appendectomy 


\section{Latar Belakang}

Appendicitis

merupakan

peradangan apendik vermivormis dan merupakan penyebab masalah abdomen yang paling sering (Dermawan \& Rahayuningsih, 2010; dikutip dari jurnal Elma 2018). Kejadian apendicitis di dunia mencapai 321 juta kasus tiap tahun dan statistik di Amerika mencatat setiap tahun terdapat 20-35 juta kasus apendicitis (Rabie, 2006; dikutip dari jurnal Aan, 2017). Di Indonesia, jumlah pasien yang menderita penyakit apendicitis berjumlah sekitar 7\% dari jumlah penduduk di Indonesia atau sekitar 179.000 orang.

Berdasarkan data dari Dinas Kesehatan Jawa Tengah (2009), jumlah kasus kesehatan appendicitis dilaporkan sebanyak 5.980 dan 177 diantaranya menyebabkan kematian. Jumlah penderita appendicitis tertinggi ada di Kota Semarang, yakni 970 orang. (Moch Fatkan, 2018). Appendiktomy merupakan tindakan pembedahan untuk mengangkat appendiks yang dilakukan untuk menurunkan resiko perforasi. Tindakan appendiktomy ini dapat menyebabkan terjadinya perubahan kontinuitas jaringan tubuh. (Jamaludin, 2017).

Dalam jurnal Moch Fatkan dkk (2018) appendiktomy adalah prosedur pembedahan yang dapat menyebabkan nyeri. Klien post appendiktomy membutuhkan perawatan yang maksimal yang dapat membantu pemulihan fungsi tubuh. Salah satu terapi nonfarmakologis yang dapat mengurangi nyeri adalah kompres hangat, nafas dalam, relaksasi spiritual, dan pemberian analgesik. Namun dalam penelitian ini peneliti akan mencoba dengan tehnik nonfarmakologis relaksasi genggam jari. Tehnik relaksasi genggam jari dengan tindakan untuk penanganan nyeri yang mempunyai beberapa tindakan. Dalam keadaan relaksasi secara alamiah akan memicu pengeluaran hormon endorphin, hormon ini ialah analgesik alami tubuh sehingga nyeri akan berkurang (Sulung N, Dian Rani S, 2007; dikutip dalam Asni Hasaini, 2019).

\section{Metode Penelitian}


Metode penelitian yang digunakan pada penelitian ini adalah literature review, yaitu mengumpulkan dan menganalisis artikel-artikel penelitian mengenai penerapan relaksasi genggam jari. Penelusuran artikel dilakukan dengan pendekatan data (database) seperti Google Scholar atau Google Cendekia dengan menggunakan kata kunci seperti "genggam jari + post appendiktomy", "efektifitas genggam jari + nyeri + post appediktomy", genggam jari post appendiktomy + nyeri”, "penurunan nyeri post appendiktomy", "tehnik relaksasi genggam jari post appendiktomy". Artikel yang dipilih adalah artikel yang dipublikasikan sejak tahun 2015 sampai dengan 2020 yang dapat diakses fulltext dalam format pdf berbahasa Indonesia. Analisa data dilakukan dengan cara mendiskusikan dan meringkas literatur kemudian membandingkan beberapa literatur dan selanjutnya dituangkan dalam pembahasan. Dalam mereview sebuah literatur bisa melakukannya dengan beberapa cara, diantaranya: Mencari kesamaan (Simmiliarity), mencari ketidaksamaan (Contrast), memberikan pandangan (Criticze), membandingkan (Compare) dan meringkas (Summarize).

\section{Hasil}

Hasil Analisa dan sintesis dari 5 artikel menunjukan bahwa pengaruh teknik relaksasi genggam jari berpengaruh terhadap penurunan nyeri post operasi apendiktomi. Pelaksanaan terapi genggam jari ini diterapkan pada pasien post operasi apendiktomi. Hasil Analisa dan sintesis ditampilkan dalam Tabel 1.

Tabel 1. Ringkasan dari literatur tentang Pengaruh Terapi Genggam Jari Terhadap Penurunan Nyeri Pada Klien Post Operasi Apendiktomi

\begin{tabular}{|c|c|c|c|c|c|}
\hline No & $\begin{array}{l}\text { Nama } \\
\text { Penulis }\end{array}$ & Judul Artikel & $\begin{array}{c}\text { Metode } \\
\text { Penelitian }\end{array}$ & $\begin{array}{c}\text { Subjek } \\
\text { Penelitian }\end{array}$ & Hasil \\
\hline 1. & $\begin{array}{l}\text { Ahmad } \\
\text { Aswad, } \\
2020\end{array}$ & $\begin{array}{l}\text { Relaksasi } \\
\text { Finger Hold } \\
\text { Untuk } \\
\text { Penuruanan } \\
\text { Nyeri pasien }\end{array}$ & $\begin{array}{l}\text { Metode yang } \\
\text { digunakan } \\
\text { quasi } \\
\text { experiment } \\
\text { dengan } \\
\text { pendekatan }\end{array}$ & $\begin{array}{l}\text { Pengambilan } \\
\text { sampel adalah } \\
\text { menggunakan } \\
\text { non- } \\
\text { probability } \\
\text { sampling }\end{array}$ & \begin{tabular}{lr}
\multicolumn{2}{l}{ Berdasarkan data } \\
hasil penelitian \\
diketahui & selisih \\
skala & nyeri \\
sebelum & \\
dilakukan & teknik
\end{tabular} \\
\hline
\end{tabular}




\begin{tabular}{|c|c|c|c|c|c|}
\hline \multirow[t]{2}{*}{ No } & $\begin{array}{l}\text { Nama } \\
\text { Penulis }\end{array}$ & Judul Artikel & $\begin{array}{c}\text { Metode } \\
\text { Penelitian }\end{array}$ & $\begin{array}{c}\text { Subjek } \\
\text { Penelitian }\end{array}$ & Hasil \\
\hline & & $\begin{array}{l}\text { Post Operasi } \\
\text { Appendiktomi }\end{array}$ & $\begin{array}{l}\text { pretest - } \\
\text { postest tanpa } \\
\text { kelompok } \\
\text { kontrol }\end{array}$ & $\begin{array}{l}\text { dengan teknik } \\
\text { accidental } \\
\text { sampling, } \\
\text { sebanyak } \\
\text { responden }\end{array}$ & 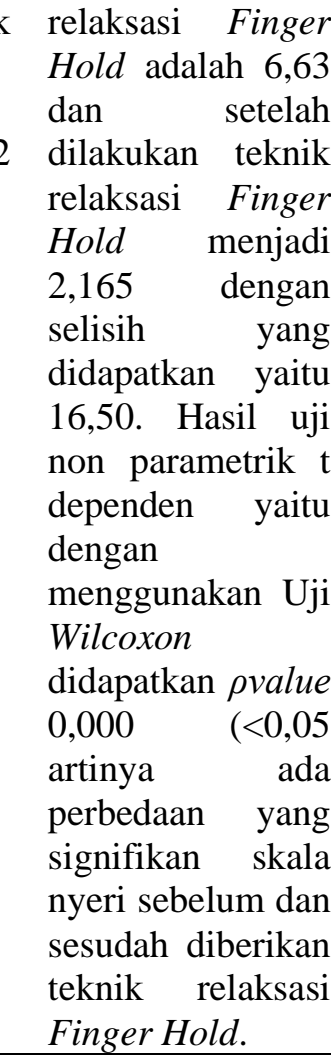 \\
\hline 2. & $\begin{array}{l}\text { Asni } \\
\text { Hasaini, } \\
2019\end{array}$ & $\begin{array}{l}\text { Efektifitas } \\
\text { Relaksasi } \\
\text { Genggam Jari } \\
\text { Terhadap } \\
\text { Penurunan } \\
\text { Nyeri Pada } \\
\text { Pasien Post } \\
\text { Op } \\
\text { Appendiktomi }\end{array}$ & $\begin{array}{l}\text { Metode yang } \\
\text { digunakan } \\
\text { Pre- } \\
\text { Eksperimental } \\
\text { dengan } \\
\text { rancangan } \\
\text { one-group } \\
\text { pre-post test } \\
\text { design. }\end{array}$ & $\begin{array}{l}\text { sampel } \\
\text { sebanyak } 15 \\
\text { orang } \\
\text { responden } \\
\text { dengan } \\
\text { simple } \\
\text { random } \\
\text { sampling. } \\
\text { Instrument } \\
\text { menggunakan } \\
\text { lembar } \\
\text { observasi dan } \\
\text { dianalisis } \\
\text { bivariat } \\
\text { dengan } \\
\text { Wilcoxon. }\end{array}$ & $\begin{array}{l}\text { Ada efek } \\
\text { relaksasi } \\
\text { genggam jari } \\
\text { terhadap } \\
\text { penurunan nyeri } \\
\text { pada pasien post } \\
\text { op appendiktomy } \\
\text { di Ruang Bedah } \\
\text { (Al-Muizz) } \\
\text { RSUD Ratu } \\
\text { Zalecha } \\
\text { Martapura. }\end{array}$ \\
\hline 3. & $\begin{array}{l}\text { Abdul } \\
\text { Hayat, } \\
2020\end{array}$ & $\begin{array}{l}\text { Pengaruh } \\
\text { Teknik } \\
\text { Relaksasi } \\
\text { Genggam Jari } \\
\text { Terhadap } \\
\text { Penurunan } \\
\text { Skala Nyeri } \\
\text { Pada Pasien }\end{array}$ & $\begin{array}{l}\text { Penelitian } \\
\text { menggunakan } \\
\text { metode Pre- } \\
\text { experimental } \\
\text { design one } \\
\text { group pre-test } \\
\text { post-test } \\
\text { design. }\end{array}$ & $\begin{array}{l}\text { Pengambilan } \\
\text { sampel } \\
\text { menggunakan } \\
\text { teknik non } \\
\text { probability } \\
\text { sampling } \\
\text { dengan } \\
\text { pendekatan }\end{array}$ & $\begin{array}{l}\text { Terdapat } \\
\text { pengaruh tehnik } \\
\text { relaksasi } \\
\text { genggam jari } \\
\text { terhadap skala } \\
\text { nyeri pasien post } \\
\text { operasi } \\
\text { appendictomy }\end{array}$ \\
\hline
\end{tabular}




\begin{tabular}{|c|c|c|c|c|c|}
\hline No & $\begin{array}{l}\text { Nama } \\
\text { Penulis }\end{array}$ & Judul Artikel & $\begin{array}{l}\text { Metode } \\
\text { Penelitian }\end{array}$ & $\begin{array}{c}\text { Subjek } \\
\text { Penelitian }\end{array}$ & Hasil \\
\hline & & $\begin{array}{l}\text { Post } \\
\text { Appendictomy }\end{array}$ & & $\begin{array}{l}\text { consecutive } \\
\text { sampling } \\
\text { dengan } \\
\text { jumlah } \\
\text { sampel } 19 .\end{array}$ & $\begin{array}{l}\text { dengan nilai p } \\
\text { value }=0,000<\alpha \\
0,05 \text { dengan } \\
\text { perhitungan } \\
\text { menggunakan uji } \\
\text { Wilcoxon Signed } \\
\text { Ranks Test. }\end{array}$ \\
\hline 4. & $\begin{array}{l}\text { Ria } \\
\text { Ariani } \\
\text { Rasyid, } \\
2019\end{array}$ & $\begin{array}{l}\text { Pengaruh } \\
\text { Teknik } \\
\text { Relaksasi } \\
\text { Genggam Jari } \\
\text { Terhadap } \\
\text { Penurunan } \\
\text { Skala Nyeri } \\
\text { Pada Klien } \\
\text { Post Operasi } \\
\text { Apendisitis }\end{array}$ & $\begin{array}{l}\text { Metode } \\
\text { penelitian } \\
\text { menggunakan } \\
\text { pre- } \\
\text { eksperimental } \\
\text { dengan } \\
\text { pendekatan } \\
\text { Non- } \\
\text { equivalent } \\
\text { Control } \\
\text { Group Design }\end{array}$ & $\begin{array}{l}\text { Sampling } \\
\text { menggunakan } \\
\text { total } \\
\text { Sampling. } \\
\text { Sampel } \\
\text { sebanyak } 36 \\
\text { responden. }\end{array}$ & $\begin{array}{l}\text { Ada pengaruh } \\
\text { relaksasi } \\
\text { genggam jari } \\
\text { terhadap } \\
\text { penurunan nyeri } \\
\text { pada pasien post } \\
\text { operasiapendisitis } \\
\text { dan hasil } \\
\text { independent } t \text { test } \\
\text { ada perbedaan } \\
\text { skala nyeri } \\
\text { dengan p value }= \\
0,000 \leq \alpha=0,05\end{array}$ \\
\hline 5. & $\begin{array}{l}\text { Neila } \\
\text { Sulung, } \\
2017\end{array}$ & $\begin{array}{l}\text { Teknik } \\
\text { Relaksasi } \\
\text { Genggam Jari } \\
\text { Terhadap } \\
\text { Intensitas } \\
\text { Nyeri Pada } \\
\text { pasien Post } \\
\text { Appendiktomi }\end{array}$ & $\begin{array}{l}\text { Metode } \\
\text { penelitian } \\
\text { menggunakan } \\
\text { desain Quasy } \\
\text { Experiment } \\
\text { dengan } \\
\text { rancangan } \\
\text { One Group } \\
\text { Pre-test Post- } \\
\text { test. }\end{array}$ & $\begin{array}{l}\text { Teknik } \\
\text { pengambilan } \\
\text { sampel } \\
\text { menggunakan } \\
\text { teknik } \\
\text { Purposive } \\
\text { sampling. }\end{array}$ & 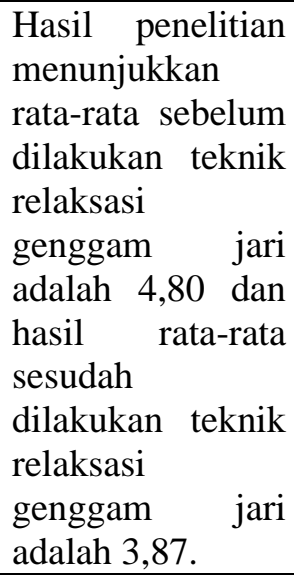 \\
\hline
\end{tabular}

\section{Pembahasan}

Berdasarkan hasil analisis kelima jurnal penelitian yang telah dilakukan literature review diatas, terdapat persamaan dan ketidaksamaan pada masing-masing jurnal penelitian. Topik penelitian pada literature ini mempunyai persamaan baik penelitian yang dilakukan oleh Ahmad (2020), Asni (2019), Abdul (2020), Ria (2019), Neila (2017). Kelima jurnal yang telah dilakukan literature review ini yaitu pengaruh teknik relaksasi genggam jari terhadap penurunan 
nyeri pada klien post operasi apendiktomi.

Metode penelitian yang penulis review semuanya menggunakan metode penelitian eksperimental. Terdapat dua metode penelitian yang dilakukan oleh Ahmad (2020), dan Neila (2017), keduanya sama-sama menggunakan metode Quasy-Eksperiment dan ada tiga penelitian yang sama dilakukan oleh Asni (2019), Abdul (2020), Ria (2019), ketiganya sama-sama menggunakan metode PreEksperimental. Rukminingsih (2020), mengatakan desain yang diklarifikasikan sebagai PreEksperimental adalah eksperimen hanya melibatkan satu kelompok dan tidak ada kelompok perbandingan atau kontrol. Desain ini dikategorikan desain eksperimen yang paling lemah karena tidak ada kelompok pengontrolnya dari variabel asing. Sehingga, tidak ada jaminan untuk menentukan jika perlakuan mempunyai efek pada hasil. Selain memiliki kelemahan metode ini memiliki kelebihan yaitu diberi tes awal dan tes akhir disamping perlakuan terhadap kelompok tersebut. Sedangkan, metode penelitian Quasy Eksperiment merupakan bentuk desain yang melibatkan dua kelompok paling sedikitnya. Satu kelompok sebagai kelompok eksperimen dan satu kelompok lainnya sebagai kelompok kontrol. Kelebihan metode penelitian ini yaitu tidak memapunyai batasan yang ketat terhadap pemilihan sampel dan dapat mengontrol ancaman-ancaman validitas.

Tehnik genggam jari tersebut disebut juga finger hold. Tehnik relaksasi genggam jari, yang dimana tehnik ini mudah digunakan oleh siapapun yang berhubungan dengan jari tangan dan aliran energy didalam tubuh, terdapat kombinasi yaitu relaksasi nafas dalam, meggunakan waktu yang relatif singkat.

Menggenggam jari sambil mengatur nafas (relaksasi) dapat mengurangi ketegangan fisik dan emosi, karena genggaman jari akan menghangatkan titik-titik keluar dan masuknya energy meridian (energy channel) yang terletak pada jari tangan kita. Titik-titik refleksi pada 
tangan akan memberikan rangsangan secara reflex (spontan) pada saat genggaman. (Sulung pengontrolnya dari variabel asing. Sehingga, tidak ada jaminan untuk menentukan jika perlakuan mempunyai efek pada hasil. Selain memiliki kelemahan metode ini memiliki kelebihan yaitu diberi tes awal dan tes akhir disamping perlakuan terhadap kelompok tersebut. Sedangkan, metode penelitian Quasy Eksperiment merupakan bentuk desain yang melibatkan dua kelompok paling sedikitnya. Satu kelompok sebagai kelompok eksperimen dan satu kelompok lainnya sebagai kelompok kontrol. Kelebihan metode penelitian ini yaitu tidak memapunyai batasan yang ketat terhadap pemilihan sampel dan dapat mengontrol ancamanancaman validitas.

Pendekatan yang dilakukan oleh Ahmad (2020), menggunakan pendekatan Pretest-Postest tanpa kelompok kontrol yang artinya jenis ini tidak terdapat kelompok control dan hanya satu kelompok yang diukur dan diamati gejala-gejala yang muncul setelah diberi perlakuan (postes). Berbeda dengan pendekatan yang dilakukan pada penelitian Asni (2019), Abdul (2020), Neila (2017), menggunakan pendekatan one group pre-post test design dimana dalam penelitian ini tidak ada kelompok perbandingan dengan melakukan pengukuran sebelum dan setelah perlakuan. Ria (2019), juga menggunakan pendekatan yang berbeda dengan pendekatan non-equivalent group design yaitu desain yang terdapat satu kelompok yang dipilih secara acak atau random, desain ini melibatkan satu objek, satu diberikan relaksasi genggam jari (kelompok eksperimen). Dua kelompok yang ada diberi pre test kemudian satu kelompok eksperimen diberi perlakuan dan terakhir dua kelompok diberi post test.

Mekanisme relaksasi genggam jari ini dijelaskan melalui teori gatecontrol yang menyatakan bahwa stimulasi kutaneous mengaktifkan transmisi serabut saraf sensori A-beta yang lebih besar dan lebih cepat. 
Penelitian yang dilakukan oleh Neila Sulung dkk, (2017) pada pasien post appendiktomy di RSUD Dr. Achmad Mochtar Bukittinggi menunjukkan hasil bahwa pelaksanaan tehnik relaksasi genggam jari berpengaruh terhadap pengurangan rasa nyeri insisi post appendiktomy.

Hasil yang sama juga diperoleh dalam penelitian yang dilakukan oleh Asni Hasaini (2019) yang melakukan relaksasi genggam jari di ruang Bedah Al-Muizz RSUD Ratu Zalecha Martapura dengan hasil ada penurunan nyeri pasien post op appendicitis. Pada tahun yang sama juga dilakukan penelitian oleh Ria Ariani dkk, (2019) bahwa tehnik relaksasi genggam jari juga pengukuran sebelum dan setelah perlakuan. Ria (2019), juga menggunakan pendekatan yang berbeda dengan pendekatan nonequivalent group design yaitu desain yang terdapat satu kelompok yang dipilih secara acak atau random, desain ini melibatkan satu objek, satu diberikan relaksasi genggam jari (kelompok eksperimen). Dua kelompok yang ada diberi pre test kemudian satu kelompok eksperimen diberi perlakuan dan terakhir dua kelompok diberi post test.

Teknik pengambilan sampling pada kelima jurnal ini terdapat ketidaksamaan. Penelitian yang dilakukan oleh ahmad (2020), yaitu menggunakan accidental sampling dengan jumlah sampel 32 responden. Sugiyono (2009), mengatakan bahwa accidental sampling adalah teknik penentuan sampel berdasarkan kebetulan, yaitu konsumen yang secara kebetulan atau insidental bertemu dengan peneliti dapat digunakan sebagai sampel, bila dipandang orang yang kebetulan ditemui itu cocok sebagai sumber data. Asni (2019), menggunakan simple random sampling dengan jumlah sampel sebanyak 15 orang. Dikatakan simple (sederhana) karena pengambilan keputusan anggota sampel dari populasi dilakukan secara acak tanpa memperhatikan strata yang ada dalam populasi itu. Cara demikian dilakukan bila anggota populasi dianggap homogen. Abdul (2020), Pengambilan sampel menggunakan teknik non probability sampling dengan pendekatan consecutive 
sampling dengan jumlah sample 19 orang. Sastroasmoro (2014), mengatakan bahwa consecutive sampling adalah teknik penentuan sampling dimana semua subyek yang datang dan memenuhu kriteria pemilihan dimasukkan dalam penelitian sampai jumlah subyek yang diperlukan terpenuhi. Ria (2019), yaitu menggunakan total sampling. Sehingga, sampel dalam penelitian ini berjumlah 36 responden. Sugiyono (2014), mengatakan bahwa teknik total sampling adalah teknik penentuan sampel bila semua anggota populasi digunakan sebagai sampel. Neila (2017), menggunakan teknik pengambilan sampel secara purposive sampling yaitu didasarkan pada suatu pertimbangan tertentu yang sesuai dengan kriteria sebanyak 20 orang yang terdiri dari 10 orang kelompok kontrol dan 10 orang kelompok perlakuan. Menurut Sugiyono (2014), teknik Non probability sampling dengan pendekatan purposive sampling adalah teknik penarikan sampel yang tidak memberikan peluang bagi setiap unsur atau anggota populasi untuk dipilih menjadi sampel. Teknik ini didasarkan pada suatu pertimbangan tertentu yang dibuat oleh peneliti sendiri, berdasarkan ciri atau sifatsifat yang sudah diketahui sebelumnya. Kelebihan teknik sampling ini adalah dapat digunakan apabila probability sampling tidak dapat digunakan sama sekali dan bila pengetahuan peneliti tentang topik yang dihadapi sangat memadai. Adapun kekurangan dari teknik sampling ini yaitu perlu kejelian peneliti dalam mendefinisikan populasi dan membuat pertimbangannya.

Hasil penelitian yang ditelaah dalam literature review ini menunjukan bahwa ada pengaruh terapi genggam jari terhadap penurunan nyeri pada klien post operasi apendiktomi (Ahmad (2020), Asni (2019), Abdul (2020), Ria (2019), dan Neila (2017). Penurunan skala nyeri ini terjadi karena dengan menggegam jari sambil menarik nafas dalam relaksasi dapat mengurangi nyeri dan menyembuhkan ketegangan fisik dan emosi. Sebelum dilakukan relaksasi genggam terhadap penurunan tingkat nyeri post op apendiktomi, dikategorikan nyeri 
sedang 4 dan setelah dilakukan relaksasi genggam jari terhadap penurunan tingkat nyeri post op apendiktomi, dikategorikan nyeri ringan 1,73. Teknik relaksasi Finger Hold dapat menghangatkan titik-titik keluar dan masuknya energi pada median (energy channel) yang terletak pada jari tangan, sehingga mampu memberikan rangsangan secara reflex atau spontan pada saat genggaman. Rangsangan yang diperoleh nantinya akan mengalirkan gelombang menuju ke otak, kemudian dilanjutkan ke saraf pada organ tubuh yang mengalami gangguan dan sumbatan dijalur energi menjadi lancar. Dengan pengaturan nafas melalui genggaman jari, ketegangan serta kecemasan pasien dapat dikontrol, pasien akan merasa rileks dan santai yang selanjutnya akan menimbulkan tingkat kenyamanan yang lebih baik sehingga intensitas nyeri dapat menurun. Perlakuan relaksasi genggam jari akan menghasilkan impuls yang dikirim melalui serabut saraf aferen non nosiseptor. Serabut saraf non nosiseptor mengakibatkan "pintu gerbang" tertutup sehingga stimulus nyeri terhambat dan berkurang. Gerbang dapat ditemukan di sel-sel agar-agar diujung sumsum tulang belakang, thalamus, dan otak kecil. Maka dari itu teknik relaksasi genggam jari efektif dalam menurunkan nyeri post operasi.

Hasil penelitian ini juga sejalan dengan literatur review yang dijelaskan oleh (Ahmad Muzaki, Basuki Widiyanto, 2021) meunjukan bahwa ada pengaruh efek relaksasi genggam jari terhadap penurunan nyeri pada pasien post op appendiktomy.

\section{Kesimpulan}

Berdasarkan kelima jurnal penelitian yang telah di review terdapat persamaan dan perbedaan setiap penelitian. Metode penelitian yang penulis review semuanya menggunakan metode penelitian eksperimental. Terdapat dua metode penelitian yang menggunakan metode Quasy-Eksperiment dan ada tiga penelitian yang menggunakan metode Pre-Eksperimental. 


\section{Ucapan Terimakasih}

Penulis mengucapkan terima kasih kepada Direktur Akper Pemkab Purworejo dan Ketua Lembaga Penelitian dan Pengabdian Masyarakat yang telah memberikan dukungan dalam penyelesaian publikasi ini.

\section{Daftar Pustaka}

Ahmad Muzaki, Basuki Widiyanto, W. E. Y. (2021). Literatur review: penerapan tehnik relaksasi genggam jari dalam Mengurangi intensitas nyeri pada klien Post appendiktomy. Nursing Science Journal (NSJ), 2(1), 39-45.

Aini, Dwi Nur, Tamrin., \& Rilasadi. (2017). Pengaruh Tehnik Relaksasi Genggam Jari Terhadap Penurunan Tingkat Nyeri Pasien Post Operasi Appendiktomy Di RSUD Dr. H. Soewondo Kendal. Diakses pada tanggal 04 Juni 2020, pukul 22.00 WIB.

Andriyani, Elma R. (2018). Penerapan Mobilisasi Dini Pada Pasien Gangguan Pemenuhan Activities Daily Living Post Appendiktomy Di RSUD Sleman, Yogyakarta. Diakses pada 7 Oktober 2019, pukul 21.48 WIB.
Fatkan, Moch, Yusuf, Ah., \& Herisanti, Wesiana. (2018). Pengaruh Kombinasi Mobilisasi Dini Dan Relaksasi Spiritual Terhadap Tingkat Nyeri Klien Post Operasi Apendektomi, Surabaya. Vol 5. Diakses pada 7 Oktober 2019, pukul 22.20 WIB.

Hasaini, Asni. (2019). Efektifitas Relaksasi Genggam Jari Terhadap Penurunan Nyeri Pada Pasien Post Op Appendiktomi Di Ruang Bedah (Al-Muizz) RSUD Ratu Zalecha Martapura. Diakses pada tanggal 02 Mei 2020 pukul 20.00 WIB.

Hayat, Abdul, Ernawati \& Aryanti, (2020). Pengaruh Tehnik relaksasi genggam jari terhadap penurunan nyeri di RSUD P3 Gerung Lombok Barat. Vol 2 (1). Diakses pada tanggal 02 Mei 2020, pukul $21.00 \mathrm{WIB}$.

Jamaludin, Ulya, Nur.K. (2017). Pengaruh Terapi Guided Imagery Dan Iringan Musik Terhadap Penurunan Nyeri Pada Pasien Dengan Post Apendiktomi Hari I di Ruang 
Cempaka RSUD Sunan

Kalijaga Demak. Vol 4 (2).

Diakses pada 25 Februari

2020, pukul 21.00 WIB.

Rasyid, Ria Ariani, Norma., \& Samaran Elisabet. (2019).

Pengaruh Tehnik Relaksasi Genggam Jari Terhadap

Penurunan Skala Nyeri Pada Klien Post Operasi

Apendicitis. Vol XIII (02). Diakses pada tanggal $02 \mathrm{Mei}$ 2020, pukul 21.00 WIB.Sulung, Neila., \& Rani, Sarah Dian. (2017).

Sutandi, Aan., \& Siamboton, Flora.R. (2017). Hubungan

Tingkat Pengetahuan Tentang Mobilisasi terhadap kemampuan mobilisasi pada pasien post operasi appendiktomi, vol 3. Diakses pada 20 Desember 2019, pukul 22.30 WIB. 